\title{
Effect of Ohmic heating on functionality of sodium caseinate - A relationship with protein gelation
}

\author{
Thais Caldas Paiva Moreira ${ }^{\mathrm{a}}$, Ricardo N. Pereira ${ }^{\mathrm{b}, *}$, António A. Vicente ${ }^{\mathrm{b}}$, Rosiane Lopes da Cunha ${ }^{\mathrm{a}}$ \\ a Department of Food Engineering (DEA), Faculty of Food Engineering (FEA), University of Campinas (UNICAMP), Rua Monteiro Lobato, 80; Campinas-SP, CEP: 13083- \\ 862, Brazil \\ ${ }^{\mathrm{b}}$ Centre of Biological Engineering (CEB), University of Minho (UMINHO), Campus Gualtar, 4710 Braga, Portugal
}

\section{A R T I C L E I N F O}

\section{Keywords:}

Ohmic heating

Protein functionality

Sodium caseinate

Acid systems

Moderate electric fields

Water holding capacity

\begin{abstract}
A B S T R A C T
Sodium caseinate (NaCAS) is widely used in the food industry to provide nutritional and functional benefits. This work deals with the effects of applying moderate electric fields (MEF) of different intensity - ranging from $2 \mathrm{~V} \cdot \mathrm{cm}^{-1}$ to $17 \mathrm{~V} \cdot \mathrm{cm}^{-1}$ - on the physical and functional properties of NaCAS solutions during Ohmic heating $(\mathrm{OH})$ at $95^{\circ} \mathrm{C}$. Self-standing gels were produced regardless the heating technique applied (i.e. conventional or $\mathrm{OH}$ ), and these gels were much more prone to physical rupture when compared with the ones produced from unheated NaCAS. Interestingly, $\mathrm{OH}$ treatment formed gels with lower values of strain at rupture and water holding capacity than unheated samples; this pattern was not observed for gels obtained through the conventional heating treatment (at $0 \mathrm{~V} \cdot \mathrm{cm}^{-1}$ ). These effects may be linked with disturbances of the distribution of random coil structures and enhanced solubility of NaCAS at its isoelectric point, reducing aggregation and impairing the development of a more compact protein network. Results show that $\mathrm{OH}$ presents potential to be used as volumetric heating tool for NaCAS solubilization and for the production of distinctive acidified systems.
\end{abstract}

\section{Introduction}

Caseins are an important source of protein in functional foods and are particularly important in preventing osteoporosis and reducing hypertension (Huppertz \& Patel, 2012; Snyder et al., 2007). Caseins in milk consist in $\alpha_{s 1^{-}}, \alpha_{\mathrm{s} 2^{-}}, \beta$ - and $\kappa$-caseins, and differ by phosphoseryl groups (amount and distributions) and precipitation sensitivity in presence of ionic calcium (Lucey, Johnson, \& Horne, 2003). They are present in micellar form and are stabilized by coating $\kappa$-caseins; moreover, caseins are partially unfolded in solution, forming structures easily identified through experimental techniques. Generally, caseins are hydrophobic and negatively charged, thus providing a steric impediment that allows colloidal stability. Such stability depends on physiological conditions, hydrophobic bonds, cross-linked peptides or even ionic bonds (Gunasekaran \& Solar, 2012; Normal, 2000; Walstra, Wouters, Geurts, Wouters, \& Geurts, 2005).

Milk caseins can be obtained through precipitation by $\kappa$-casein cleavage, followed by precipitation at $\mathrm{pH} 4.6$ and addition of calcium in excess (casein precipitation), with a final addition of ethanol or a heating step at high temperatures (Kinsella \& Morr, 1984). Furthermore, it is important to highlight that caseins are quite stable to high temperatures since they do not coagulate at $100{ }^{\circ} \mathrm{C}$ for $24 \mathrm{~h}$, and are resistant for 20 min under $140{ }^{\circ} \mathrm{C}$, at natural milk pH (around 6.7) (Fox \& Mcsweeney, 1998).

However, isoelectric casein shows low solubility in water, but it can be converted into caseinate through dispersion of this protein in water and $\mathrm{pH}$ adjustment $(\mathrm{pH} \approx 6.7)$ with alkali addition. Usually $\mathrm{NaOH}$ is used forming sodium caseinate (Thompson et al., 2008), which is stable to heat $\left(140{ }^{\circ} \mathrm{C}\right.$ for $15 \mathrm{~min}$, at $\left.\mathrm{pH} 7\right)$ and it is an effective emulsifier, thickener, and foaming agent. Sodium caseinate is usually applied in baked food, breakfast cereals, meat products, coffee whitener, whipped toppings, instant breakfast, desserts, puff snacks and cheese analogs (Kinsella \& Morr, 1984).

It is possible to produce casein/caseinate gels from the destabilization of caseins through enzymatic or acidification processes or using a combination of both. Although there are some differences between these processes, the inhibition by low $\mathrm{pH}$ is the main restriction in the subsequent employment of bacterial cultures (e.g. for cheese production) (Kuhn, Picone, \& Cunha, 2009).

During caseins acidification, the phosphoseryl residues and carboxyl groups change their ionized state due to their proton affinity, once at neutral $\mathrm{pH}$ caseins have negative charges and are neutral near the pI, which leads to particle aggregation and to the establishment of a gel structure (Broyard \& Gaucheron, 2015). These gels are affected by

\footnotetext{
* Corresponding author.

E-mail addresses: rpereira@deb.uminho.pt (R.N. Pereira), avicente@uminho.pt (A.A. Vicente), rosiane@unicamp.br (R.L. da Cunha).
} 
concentration, composition, temperature, ionic strength, $\mathrm{pH}$ and gelation rate (Braga, Menossi, \& Cunha, 2006; Chen, Dickinson, \& Edwards, 1999; de Kruif, 1997; O'Kennedy, Mounsey, Murphy, Duggan, \& Kelly, 2006).

Ohmic heating $(\mathrm{OH})$, also called Joule heating, occurs by internal heat generation due to the internal resistance of the material to be treated (Vicente, Castro, \& Teixeira, 2005). The first application of this technology was milk pasteurization; however, the high costs involved and the corrosion of the electrodes led to the abandonment of the technology. Currently, research has allowed the application of this technology to the processing of fruits, vegetables, meat products and other foods, allowing to obtain to manufacture of products with higher quality than those by existing techniques (Pereira, Rodrigues, \& Teixeira, 2015; Pereira, Souza, Cerqueira, \& Teixeira, 2010; Vicente et al., 2005).

Thus, the main benefits of $\mathrm{OH}$ are the absence of hot surfaces, rapid and uniform heating of liquids and solids (direct and volumetric heating, ideal for processing of viscous and sensitive products), high energy efficiency, simple and environmental friendly technology and low maintenance costs. This technology also allows a very fast heating, overcoming heat transfer limitations that naturally occur during conventional thermal treatments (Pereira et al., 2015).

Recent studies indicated that the application of electric fields to globular proteins result in conformational changes in the proteins structure, which result in protein films and gels with distinctive properties (Pereira et al., 2010; Pereira, Teixeira, \& Vicente, 2011; Rodrigues et al., 2015). However, no systematic characterization has been made regarding the electrical effects (e.g. the application of moderate electric fields (MEF) and electrical frequency) of $\mathrm{OH}$ on physical and functional properties of protein structures which are highly stable to heat, such as caseins. Thereby, the aim of this study is to evaluate for the first time the electrical effects of $\mathrm{OH}$ on functional and technological properties of NaCAS, such as solubility, protein secondary structures distribution, protein aggregation and gelation as a function of the characteristics of the electric field applied during $\mathrm{OH}$.

\section{Material and methods}

\subsection{Materials}

The sodium caseinate powder $(4.16 \%$ ash, $1.13 \%$ fat, $91 \%$ protein and $6.30 \%$ moisture) was kindly provided by Alibra Ingredients Ltda. (Campinas, Brazil). Glucono- $\delta$-lactone (GDL) was purchased from Sigma Chemical Co. (St Louis, MO, USA).

\subsection{Preparation of sodium caseinate (NaCAS) solutions}

NaCAS solutions were prepared in for advanced structural characterization. Taking into consideration that NaCAS is more soluble between pH 5 and 8 (Jahaniaval, Kakuda, Abraham, \& Marcone, 2000), a stock solution of $1 \%(w / v)$ NaCAS was prepared in $0.1 \mathrm{~mol} \cdot \mathrm{L}^{-1}$ phosphate buffer at $\mathrm{pH} 7.0$ with $0.01 \%(\mathrm{w} / \mathrm{v})$ sodium azide in order to avoid any kind of microbial degradation. This solution was homogenized overnight and then centrifuged in a Mikro EBA 20 (Hettich, Germany) at $3461 \mathrm{~g}$ for $30 \mathrm{~min}$ and filtered twice in filter paper with a pore size of $0.2 \mu \mathrm{m}$ (adapted from HadjSadok, Pitkowski, Nicolai, Benyahia, \& Moulai-Mostefa, 2008). The final pH of solutions was properly checked and adjusted with $0.2 \mathrm{~mol} \cdot \mathrm{L}^{-1} \quad \mathrm{NaH}_{2} \mathrm{PO}_{4}$ or $0.2 \mathrm{~mol} \cdot \mathrm{L}^{-1} \mathrm{Na}_{2} \mathrm{HPO}_{4}$ when necessary before centrifugation and filtration.

For soluble protein and turbidity (section 2.3.1) and fluorescence (section 2.3.2) assays at a $\mathrm{pH}$ near the proteins $\mathrm{pI}$, protein precipitation was performed adding to samples an acid solution containing $0.83 \mathrm{~mol} \cdot \mathrm{L}^{-1} \mathrm{CH}_{3} \mathrm{COOH}$ and $0.2 \mathrm{~mol} \cdot \mathrm{L}^{-1} \mathrm{CH}_{3} \mathrm{COONa}$, at $\mathrm{pH} 4.6$, at a ratio 1:1 (protein solution: acid buffer). The resulting solutions were centrifuged at $17530 \mathrm{~g}$ for $10 \mathrm{~min}$ in a centrifuge Mikro 120 (Hettich,
Germany) and the supernatant was removed to be used in the assays (Pereira et al., 2011).

\subsection{NaCAS gel solutions}

For the production of protein acidified gels, NaCAS solutions were prepared as described previously (section 2.2) but with a concentration of $6 \%(w / v)$ in ultrapure water and homogenized overnight. The $\mathrm{pH}$ was adjusted using $1 \mathrm{~mol} \cdot \mathrm{L}^{-1} \mathrm{NaOH}$ and/or $\mathrm{HCl}$ in order to ensure pH 7.0. A 6\% concentration of NaCas was necessary to form hard gels with good water holding capacity using glucono- $\delta$-lactone as gelation inducer (Braga et al., 2006).

\subsection{Heating treatments}

The samples were subjected to conventional and $\mathrm{OH}$ at $95{ }^{\circ} \mathrm{C}$ for a holding time of $15 \mathrm{~min}$. Conventional heating was performed using test tubes immersed in a temperature-controlled water bath. These heating conditions were based on preliminary results (data not shown) that evidenced that heating at $95{ }^{\circ} \mathrm{C}$ for 10 to $20 \mathrm{~min}$ produced identical results regarding size and fluorescence properties and that were enough to enhance NaCAS solubility.

The application of $\mathrm{OH}$ and its MEF was done in protein solution conditioned in a cylindrical reactor $(30 \mathrm{~cm}$ total length and $2.3 \mathrm{~cm}$ inner diameter) containing two stainless steel electrodes isolated with polytetrafluorethylene (PTFE). Tensions were controlled using a function generator (Agilent 33,220 A, Bayan Lepas, Malaysia; $1 \mathrm{~Hz}-25 \mathrm{MHz}$ and $1-10 \mathrm{~V}$ ) connected to an amplifier (Peavey CS3000, Meridian, MS, USA; 0.3-170 V) (Rodrigues et al., 2015). The temperature measurement was performed through a k-type thermocouple $\left(1{ }^{\circ} \mathrm{C}\right.$, Omega, 709 , USA) placed at the geometric center of the sample volume and connected to a data logger (National Instruments, USB-9161, USA). Voltage and electric current data were also recorded during experiments. Three different intensity levels of electric field $(p<.05)$ were applied during $\mathrm{OH}$ of NaCAS solutions $-2 \mathrm{~V} \cdot \mathrm{cm}^{-1}, 5 \mathrm{~V} \cdot \mathrm{cm}^{-1}$ and $17 \mathrm{~V} \cdot \mathrm{cm}^{-1}$ - with an average time required to reach the $95^{\circ} \mathrm{C}$ of $124 \mathrm{~s}, 50 \mathrm{~s}$ and $69 \mathrm{~s}$, respectively. An electric field intensity of $9 \mathrm{~V} \cdot \mathrm{cm}^{-1}$ was applied to the acidified system (section 2.3). Electric field was calculated at the end of each heating cycle through the ratio between the applied electric voltage $(\mathrm{V})$ and distance between electrodes $(\mathrm{cm})$ necessary to keep treatment temperature at $95^{\circ} \mathrm{C}$ for $15 \mathrm{~min}$.

After heat treatment, solutions were immediately cooled in an ice bath in order to stop additional effects induced by heat. Both unheated (control) and heated samples were stored under refrigerated conditions for further testing. The samples were analyzed for particle size (section 2.6.1), charge density (section 2.6.2), turbidity and soluble protein (section 2.6.3), intrinsic fluorescence (section 2.6.4) and circular dichroism (section 2.6.5). All measurements were performed at least in triplicate.

\subsection{Acidified gelation process}

Gels were prepared with previously heated protein solutions $(6 \% w /$ $v$ ) by ohmic or conventional heating. After heating, the conventionally and ohmic heated solutions were cooled to near room temperature and GDL was added at a ratio of $0.18(w / w)$ GDL/protein as described by Braga et al. (2006). After GDL addition the samples were homogenized for $8 \mathrm{~min}$ and stored into silicon lubricated cilindrical plastic tubes (14 mm diameter) at room temperature for $48 \mathrm{~h}$.

A control sample without heating was prepared with the same ratio of GDL, homogenization and storage conditions. Gels were analyzed after $48 \mathrm{~h}$ in terms of water holding capacity (section 2.6.6) and texture (section 2.6.7). All measurements were performed in triplicate. 


\subsection{Analyses}

\subsubsection{Particle size distribution}

The particle size distribution was obtained from Dynamic Light Scattering in a Zetasizer Nano (ZEN 3600, Malvern Instruments Ltd., Malvern, UK) at $25 \pm 0.5^{\circ} \mathrm{C}$. Results were analyzed by the hydrodynamic diameter and polydispersity index of the particle size distribution (Zeta Software 7.11, Malvern Instruments Ltd., Malvern, UK).

\subsubsection{Surface charge density}

Control and heated samples were diluted ten times and their charge density (zeta potential) was measured in the Zetasizer Nano (ZEN 3600, Malvern Instruments Ltd., Malvern, UK).

\subsubsection{Turbidity and soluble protein}

Protein solubility and turbidity were evaluated by absorbance readings at $280 \mathrm{~nm}$ and $600 \mathrm{~nm}$, respectively. The assays were performed in a microplate reader (Biotek Synergy HT, Biotek, Winooski, USA), at pH 7.0 and at buffer solution $\mathrm{pH}$ 4.6.

\subsubsection{Intrinsic fluorescence}

Intrinsic fluorescence of protein solutions was followed by means of soluble tryptophan/tyrosin fluorescence value (FTrp) at excitation/ emission wavelength of $286 / 340 \mathrm{~nm}$ (Hidalgo, Riquelme, Alvarez, Wagner, \& Risso, 2012; Pereira et al., 2011). Samples were diluted a hundred-fold to avoid effects of light scattering, and then assayed in a fluorescence spectrophotometer (Hittachi, F-4500, Tokyo, Japan) at pH 7.0 and at buffer solution pH 4.6 (Birlouez-Aragon, Sabat, \& Gouti, 2002; Pereira et al., 2011).

\subsubsection{Circular dichroism (CD)}

The structure and conformation of protein solutions was analyzed by Far-UV circular dichroism. The solutions were diluted fifty-fold and evaluated at $25^{\circ} \mathrm{C}$ in the spectral range $190 \mathrm{~nm}$ to $260 \mathrm{~nm}$ with a Jasco DC 1500 spectrophotometer (Jasco Corp., Japan) using a quartz curvette with $0.1 \mathrm{~cm}$ of optical path. The spectral resolution was $0.5 \mathrm{~nm}$, and the scan speed was $50 \mathrm{~nm} / \mathrm{min}$, with a response time of $2 \mathrm{~s}$ at a bandwidth of $1 \mathrm{~nm}$. Two spectra were obtained for each sample. The molar ellipticity $[\theta]$ (deg.cm ${ }^{2} /$ decimole) was calculated by Eq. 1 , where $c$ is the sample molar concentration, $l$ is the light path length $(\mathrm{cm})$ and $\theta$ is the instrument measured ellipticity (mdeg) (Ioannou, Donald, \& Tromp, 2015).

$[\theta]=\frac{100 \cdot \theta}{c \cdot l}$

\subsubsection{Water holding capacity (WHC)}

Gel discs $(\sim 1 \mathrm{~g})$, were placed on Whatmann filter paper (Maidstone, UK) into $15 \mathrm{~mL}$ falcon tubes. Water loss was determined at room temperature by the gel weight difference before and after centrifugation at $162.47 \mathrm{~g}$ for $10 \mathrm{~min}$ in a Mikro EBA 20 (Hettich, Germany), based in the method described by Braga et al. (2006). The water holding capacity (WHC) was calculated according to Eq. 2, where Water loss $_{\text {is }}$ ise water lost in the centrifugation $(\mathrm{g})$ and Water $_{\text {gel }}$ is the water content of the gel before centrifugation.

$W H C \%=100 \cdot\left[1-\left(\right.\right.$ Waten $\left._{\text {oss }}\right) /$ Water $\left.\left._{\text {gel }}\right)\right]$

\subsubsection{Texture}

The uniaxial compression tests were performed in a TA-HD Plus texturometer (Stable Microsystems Ltda., Godalming, UK) using an aluminum cylinder geometry ( $25 \mathrm{~mm}$ diameter). Compression was performed until $80 \%$ of the original height of the sample, at a compression rate of $1 \mathrm{~mm} \cdot \mathrm{s}^{-1}$. Hencky stress $\left(\sigma_{H}\right)$ and strain $\left(\varepsilon_{H}\right)$ were calculated from the height and force values (Steffe, 1996). The break point was obtained as the maximum stress value and the Young modulus $(Y)$ from the initial linear region of the stress-strain curve.

\subsection{Statistical analyses}

Statistical analyses were performed using STATISTICA 7.0 (data analysis software system) (StatSoft Inc., Tulsa, OK, USA). Statistical significance was determined by Anova and Tukey's tests, using 0.05 as level of significance. All experiments were run at least in triplicate.

\section{Results and discussion}

\subsection{Characterization of NaCAS after heat treatment}

All samples presented a bimodal particle size distribution with peak values around $23 \mathrm{~nm}$ and $220 \mathrm{~nm}$. The larger particle size is related to NaCAS in water (around $200 \mathrm{~nm}$ ) and the smaller size can be associated to the presence of small aggregates in the buffer solution with ionic strength higher than $100 \mathrm{mM}$ (HadjSadok et al., 2008; Mezdour \& Korolczuk, 2010).

No significant differences $(p>.05)$ were observed between charge density of untreated and treated samples. Considering that caseins are highly hydrophobic and charged (Walstra et al., 2005), that charge density was stable for all $\mathrm{OH}$ processes, including $\mathrm{OH}$ carried out at different electric field intensities. Much in the same way, at the isoelectric point minimal repulsive were found, which favored hydrophobic interactions and protein aggregation (Aguilera \& Rademacher, 2004; Roefs \& Van Vliet, 1990). In general, OH and different levels of electric field intensity caused oscillations in the aggregation pattern (mean particle size of peak 1) but these were not sufficiently high or at least consistently reproducible to be considered statistically significant among comparisons (Table 1). In general, the solutions remained stable during $\mathrm{OH}$ but lack of consistency on measurements should not be overlooked, once it can be related to changes on charges organization within protein structure when heating under the influence of MEF at different intensities.

Regarding turbidity and protein solubility measurements, no significant differences $(p>.05)$ were observed at pH 7.0. (Fig. 1a and 1b) and $\mathrm{pH} 4.6$ (Fig. 1c and 1d), but in the latter it was noticed a tendency to increase protein solubility with increasing electric field intensity (Fig. 1c). All caseins contain tryptophan residues in different proportions (Normal, 2000), allowing the measurement of protein intrinsic fluorescence and thus inferring about the amount of soluble protein or protein conformational disturbances imposed by electroheating treatments (Fig. 2a and 2b). At pH 7.0 the intrinsic fluorescence remained barely constant within the several treated and untreated samples, while at $\mathrm{pH} 4.6$ an increase of peak intensity relative to tryptophan/tyrosin emission was observed between 300 and $440 \mathrm{~nm}$ (Fig. 2b) for increasing electric field intensity. The intensity of the electric field applied during heating reduced the ability of $\mathrm{NaCAS}$ to precipitate at $\mathrm{pH}$ values close to

Table 1

Surface charge density, hydrodynamic diameter and polydispersity index of protein solutions treated at $95^{\circ} \mathrm{C}$ for 15 minutes under OH. Different letters in the same column mean significant differences between the samples $(\mathrm{p}<0.05)$.

\begin{tabular}{|c|c|c|c|c|c|}
\hline \multirow[t]{2}{*}{$\mathrm{E} /\left(\mathrm{V} \cdot \mathrm{cm}^{--1}\right)$} & \multirow[t]{2}{*}{$\begin{array}{l}\text { Zeta } \\
\text { potential mV }\end{array}$} & \multicolumn{2}{|c|}{$\begin{array}{l}\text { Hydrodynamic diameter } \\
\text { (Hd) } \mathrm{nm}\end{array}$} & \multicolumn{2}{|c|}{$\begin{array}{l}\text { Polydispersity index } \\
\text { (PDI) }\end{array}$} \\
\hline & & Peak 1 & Peak 2 & Peak 1 & Peak 2 \\
\hline Control & $\begin{array}{l}--28.62 \pm \\
0.67^{\mathrm{a}}\end{array}$ & $\begin{array}{l}222.42 \pm \\
5.68^{\mathrm{a}}\end{array}$ & $\begin{array}{l}23.68 \pm \\
1.16^{\mathrm{a}}\end{array}$ & $\begin{array}{l}0.19 \pm \\
0.03^{\mathrm{a}}\end{array}$ & $\begin{array}{l}0.07 \pm \\
0.03^{\mathrm{a}}\end{array}$ \\
\hline 2 & $\begin{array}{l}--27.99 \pm \\
1.35^{\mathrm{a}}\end{array}$ & $\begin{array}{l}217.26 \pm \\
2.77^{\mathrm{a}}\end{array}$ & $\begin{array}{l}23.82 \pm \\
0.48^{\mathrm{a}}\end{array}$ & $\begin{array}{l}0.16 \pm \\
0.03^{\mathrm{a}}\end{array}$ & $\begin{array}{l}0.06 \pm \\
0.01^{\mathrm{a}}\end{array}$ \\
\hline 5 & $\begin{array}{l}--28.91 \pm \\
0.68^{\mathrm{a}}\end{array}$ & $\begin{array}{l}214.71 \pm \\
3.95^{\mathrm{a}}\end{array}$ & $\begin{array}{l}23.12 \pm \\
0.65^{\mathrm{a}}\end{array}$ & $\begin{array}{l}0.18 \pm \\
0.04^{\mathrm{a}}\end{array}$ & $\begin{array}{l}0.07 \pm \\
0.02^{\mathrm{a}}\end{array}$ \\
\hline 17 & $\begin{array}{l}--28.52 \pm \\
0.98^{\mathrm{a}}\end{array}$ & $\begin{array}{l}220.79 \pm \\
11.75^{\mathrm{a}}\end{array}$ & $\begin{array}{l}23.71 \pm \\
1.12^{\mathrm{a}}\end{array}$ & $\begin{array}{l}0.19 \pm \\
0.05^{\mathrm{a}}\end{array}$ & $\begin{array}{l}0.07 \pm \\
0.02^{\mathrm{a}}\end{array}$ \\
\hline
\end{tabular}


a)

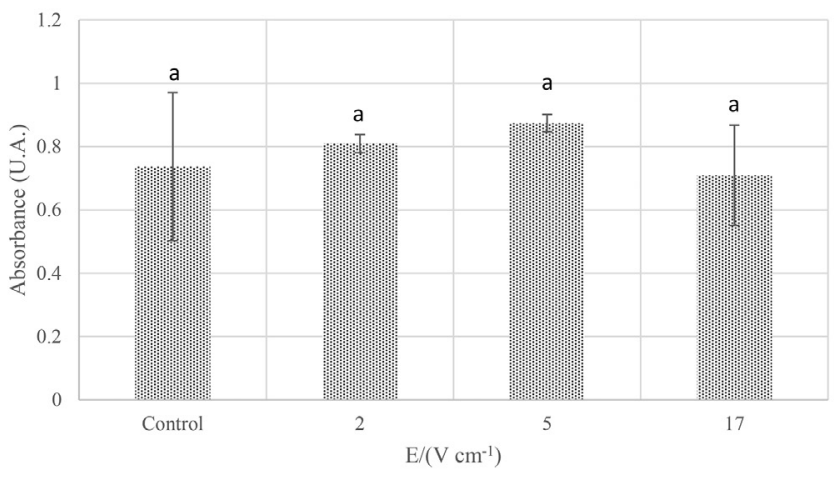

c)

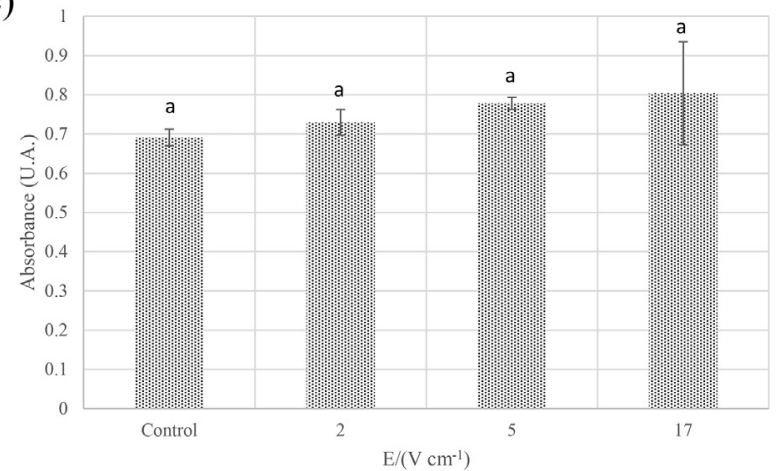

b)



d)





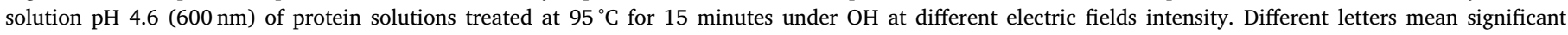
differences between the samples $(p<0.05)$.

the isoelectric point ( $\mathrm{pH} 4.6$ ).

The changes in structure and conformation of proteins could be followed using circular dichroism (CD), by identifying the main structural elements ( $\alpha$-helix, $\beta$-sheet and coil). The $\alpha$-helix structure is observed in a positive band at $190 \mathrm{~nm}$ and in a negative band at 208 and $220 \mathrm{~nm}$. In addition, $\beta$-helices, in proteins with antiparallel $\beta$-pleatead sheets, can be observed in a negative band at $218 \mathrm{~nm}$ and at $195 \mathrm{~nm}$ in a positive band. The random coil structure is identified in a positive band near $215 \mathrm{~nm}$ and a minimum ellipticity around $203 \mathrm{~nm}$, but only the latter was detected for NaCAS (Barreto et al., 2003; Greenfield, 2007). Fig. 3 shows the structures observed for NaCAS under different electric fields. CD spectra (Fig. 3) show a minimum ellipticity at $203 \mathrm{~nm}$, attributed to the random coil structure, and a pronounced shoulder at $220 \mathrm{~nm}$, attributed to the $\alpha$-helix structure (Barreto et al., 2003; Furtado, Mantovani, Consoli, Hubinger, \& da Cunha, 2017). More ordered structures can be observed at lower proportions, although the predominant structures are unordered, as described elsewhere (Furtado et al., 2017; Jahaniaval et al., 2000). Caseins show a very flexible rheomorphic structure, allowing these proteins: to be stable to temperature and denaturing agents, to have surface activity properties, and making them more prone to proteolysis (Normal, 2000). Caseins are known to be stable up to $140^{\circ} \mathrm{C}$, at neutral $\mathrm{pH}$, for many hours (McSweeney \& Fox, 2003). Interestingly, heating treatments at electric fields of 2 and $5 \mathrm{~V} \cdot \mathrm{cm}^{-1}$ tended to result in a more pronounced decrease of molar ellipticity at $203 \mathrm{~nm}$ and $220 \mathrm{~nm}$, although there were no significant differences between them (Table 2).

Overall, no significant effects were observed on particle size and protein structures distribution, even under electric field and temperature effects. However, some evidences of changes were observed in relation to protein solubility measured by fluorescence of tryptophan/ tyrosine at NaCAS isoelectric point. Further, as discussed previously, molar ellipticity at certain wavelengths (e.g. at $203 \mathrm{~nm}$ and $220 \mathrm{~nm}$ ) also points to conformational changes among different treatments, particularly at electric fields ranging from 2 to $5 \mathrm{~V} \cdot \mathrm{cm}^{-1}$. It is worth nothing that Furtado et al. (2017) observed changes in protein hydrophobicity when sodium caseinate was submitted to an ultrasound process, despite not observing alterations in the structure or charge density. It can be suggested that the electric current may have imposed, even subtly, disturbances on the charges organization and re-orientation of hydrophobic residues, as mentioned previously, leading to higher solubility when the $\mathrm{pH}$ was reduced towards the isoelectric point.

\subsection{Multivariate analysis}

The classical univariate statistical analysis not always provides accurate information about the relationships among the different studied variables, neither it allows the clustering of samples with similar characteristics (Destefanis, Barge, Brugiapaglia, \& Tassone, 2000). Multivariate statistical tools are frequently used in various fields, including protein science (Sakurai \& Goto, 2007), allowing the simultaneous analysis of more than one dependent variable. In this work, hierarchical cluster analysis (HCA) and principal component analysis (PCA) were performed to identify a global pattern of NaCAS behavior treated under different electrical field intensity by linking all characterization results discussed above - e.g. particle size distribution, loss of protein solubility, intrinsic fluorescence and protein structure.

Hierarchical cluster analysis (HCA) allowed to identify three clusters in the data set: cluster 1) composed of unheated samples; cluster 2) electro-heated samples at $5 \mathrm{~V} \cdot \mathrm{cm}^{-1}$ and $17 \mathrm{~V} \cdot \mathrm{cm}^{-1}$; and cluster 3 ) corresponding to samples electro-heated at $2 \mathrm{~V} \cdot \mathrm{cm}^{-1}$. Intrinsic fluorescence at pH $7(p<.05)$ and pH $4.6(p<.01)$, size measurements at peak $1(p<.01)$, and dichroic signals particularly at 220, 210 and $240 \mathrm{~nm}(p<.001)$ were the major criteria for assigning samples to different clusters $(p<.05)$. Other variables such as surface charge, PDI and size measurement at peak 2 were not statistically significant $(p>.05)$. Fig. 4a shows the outcome of PCA projection of variables and the aforementioned assigned clusters. The first and second 
a)

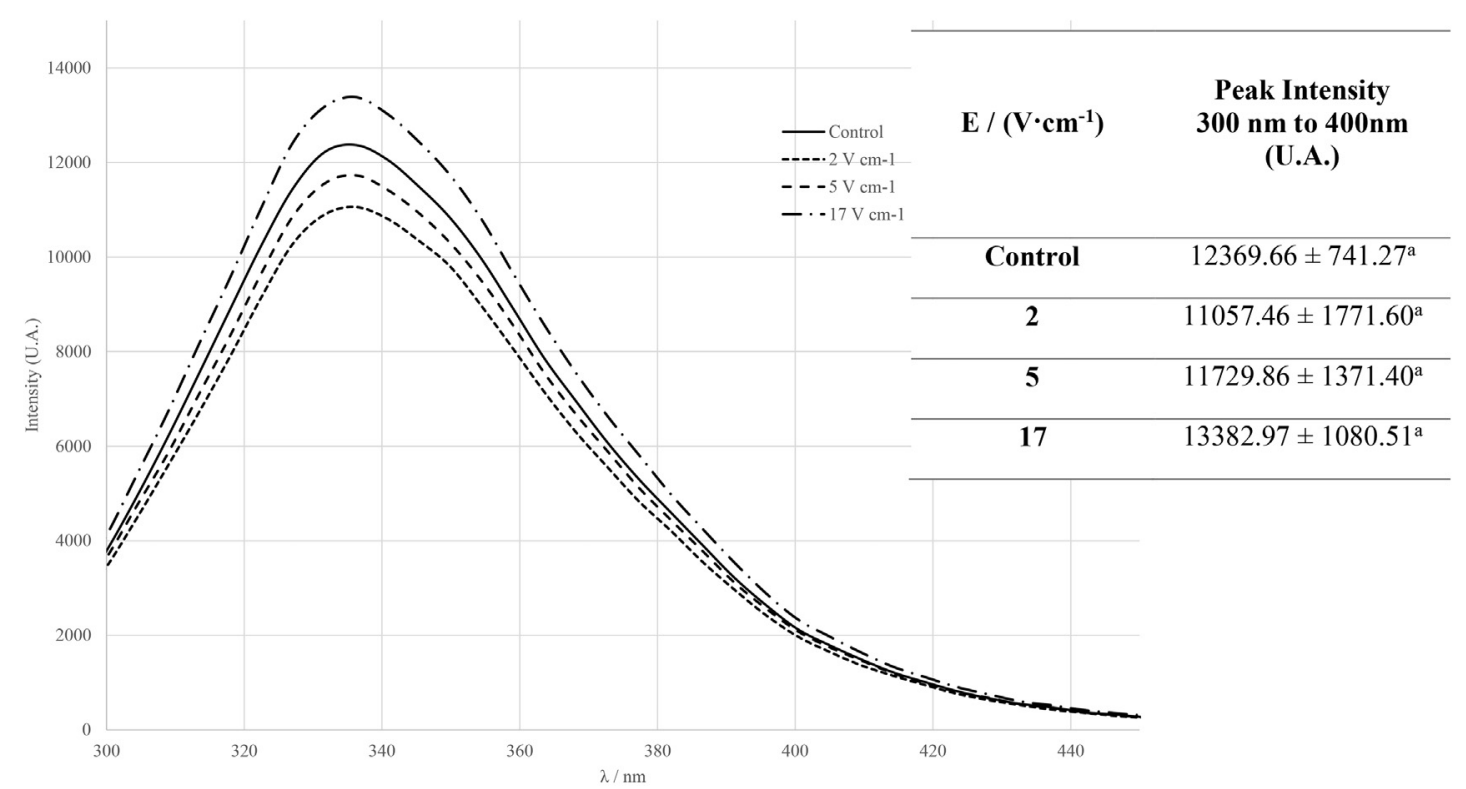

b)

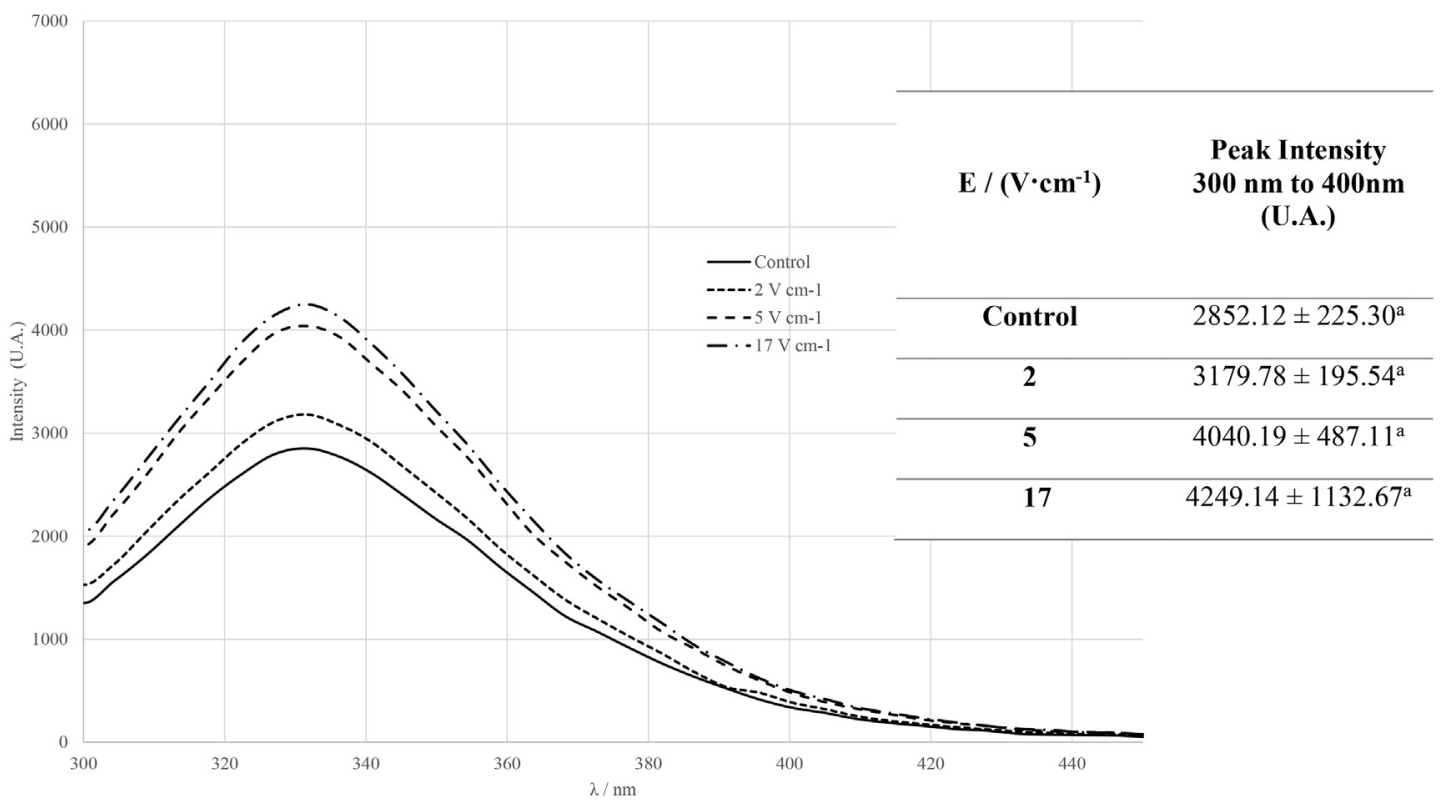

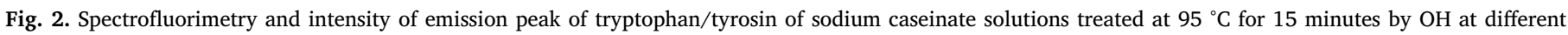

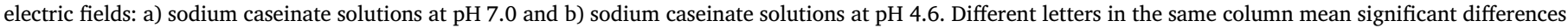
between the samples ( $\mathrm{p}<0.05$ ).

components together explained $>60 \%$ of total variation in the results.

The variability of the first component (horizontal axis) was mainly introduced by differences found in structures profile of NaCAS (CD). Unheated samples (cluster 1) presented a less negative dichroic signal at wavelengths of 203 and $220 \mathrm{~nm}$, followed by solutions treated at 5 and $17 \mathrm{~V} \cdot \mathrm{cm}^{-1}$ (cluster 2). The more negative dichroic signal of samples treated at $2 \mathrm{~V} \cdot \mathrm{cm}^{-1}$ found in CD ranging from $190 \mathrm{~nm}$ to $240 \mathrm{~nm}$ indicate the presence of more unordered protein structures. $\mathrm{CD}$ measurements and intrinsic fluorescence at $\mathrm{pH} 7$ were well correlated according to the projection of variables (Fig. 4b). In opposition, outcomes from protein surface charge were negatively correlated with $\mathrm{CD}$ measurements.
Therefore, the electro-heating treatment at $2 \mathrm{~V} \cdot \mathrm{cm}^{-1}$ resulted in an increase of protein surface charge (less negatively charged) with a concomitant decrease of dichroic signal (more negative signal at wavelengths of 203 and $220 \mathrm{~nm}$ ) or increase of unordered state of the protein. The second component (vertical axis) is explained by differences found in size measurements and solubility of protein measured by intrinsic fluorescence at $\mathrm{pH}$ 4.6. In this case, protein solubility was negatively correlated with the size measurement, which means that high protein solubility corresponds to protein particles with smaller size. Samples treated at electric fields ranging from 5 to $17 \mathrm{~V} \cdot \mathrm{cm}^{-1}$ presented higher solubility at $\mathrm{pH} 4.6$ and smaller aggregates when compared with unheated samples and samples treated at $2 \mathrm{~V} \cdot \mathrm{cm}^{-1}$. It is 




Fig. 3. Far-UV circular dichroism (CD) spectra of sodium caseinate solutions treated at $95^{\circ} \mathrm{C}$ for $15 \mathrm{~min}$ by $\mathrm{OH}$ at different electric field intensities.

Table 2

Molar ellipticity at 203 and $220 \mathrm{~nm}$. Different letters in same column mean significant differences between samples $(\mathrm{p}<0.05)$.

\begin{tabular}{lll}
\hline$E /\left(\mathrm{V} \cdot \mathrm{cm}^{-1}\right)$ & $\theta\left({ }^{\circ} \cdot \mathrm{cm}^{2} /(\mathrm{dmol})\right) \times 10^{9}$ \\
\cline { 2 - 3 } & $203 \mathrm{~nm}$ & $220 \mathrm{~nm}$ \\
\hline Control & $-2.811 \pm 0.005^{\mathrm{a}}$ & $-0.956 \pm 0.005^{\mathrm{a}}$ \\
2 & $-3.364 \pm 0.243^{\mathrm{a}}$ & $-1.156 \pm 0.088^{\mathrm{a}}$ \\
5 & $-3.113 \pm 0.330^{\mathrm{a}}$ & $-1.039 \pm 0.085^{\mathrm{a}}$ \\
17 & $-2.860 \pm 0.199^{\mathrm{a}}$ & $-1.000 \pm 0.087^{\mathrm{a}}$ \\
\hline
\end{tabular}

a)

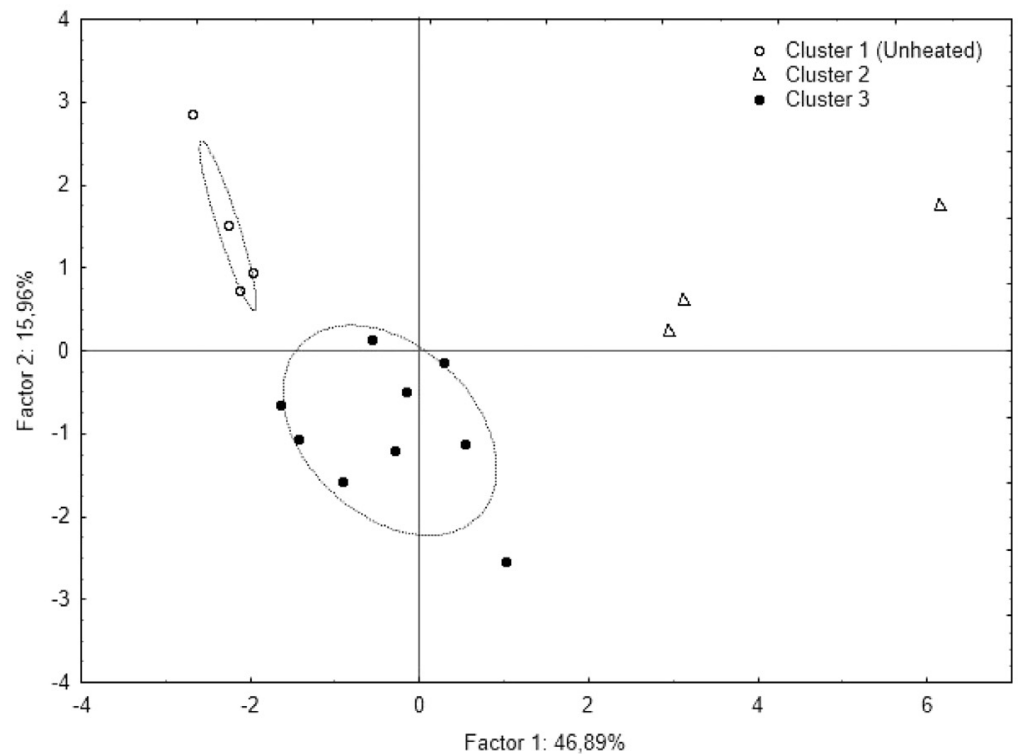

important to highlight that stronger interactions are formed near the isoelectric point (at $\mathrm{pH}=4.6$ in the case of caseins), allowing the acid coagulation of caseins (H. Chen, 2002).

\subsection{Caseinate gels}

During NaCAS acidification towards the isoelectric point, phosphoseryl residues and carboxyl groups change their ionization state. At the pI, the solubility of NaCAS is minimal favoring hydrophobic interactions and increasing protein aggregation. Gel formation occurs above a critical protein concentration and under slow acidification

\section{b)}

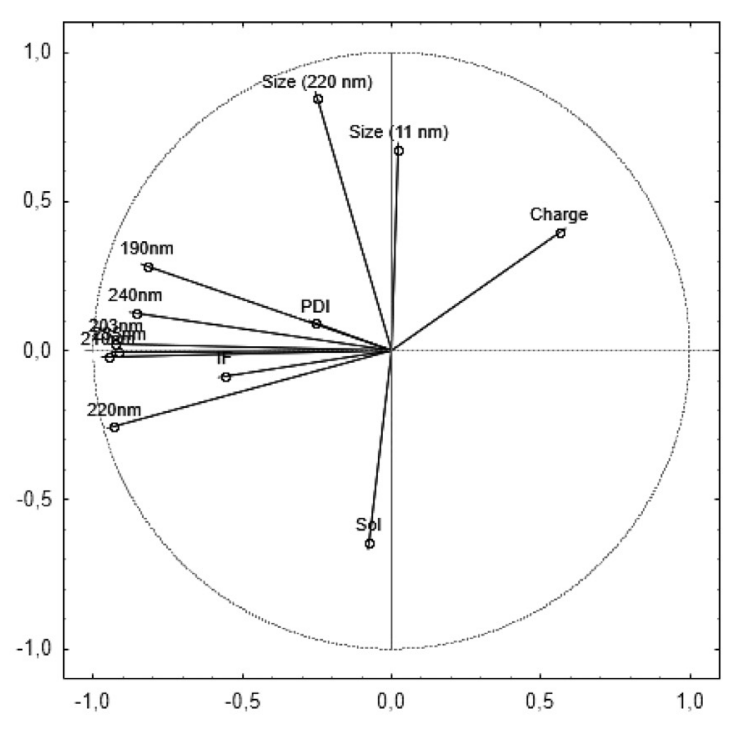

Fig. 4. Multivariate analysis of NaCAS characterization with ellipses representing $95 \%$ of mean confidence levels. a) PCA projection of variables and clusters and b) projection of variables. 
a)

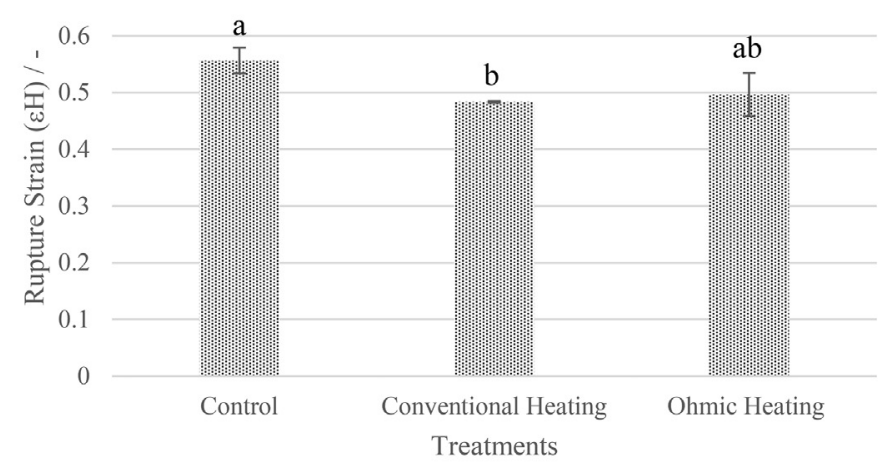

c)

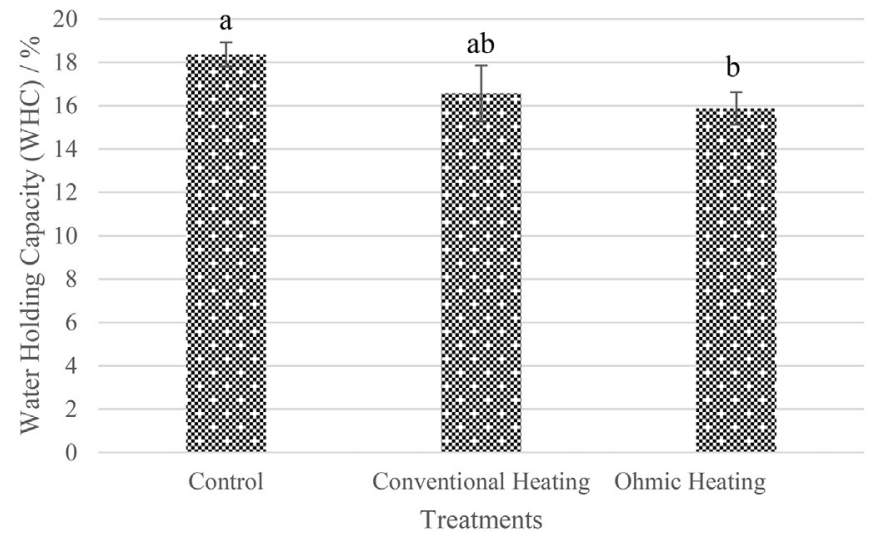

b)

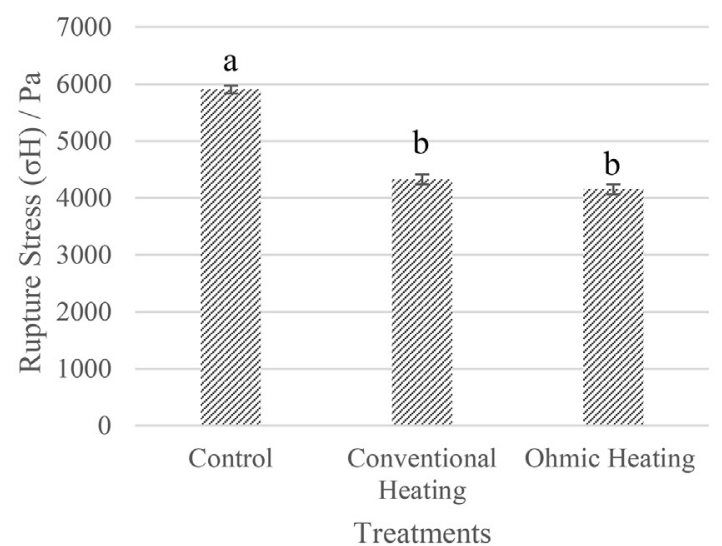

d)

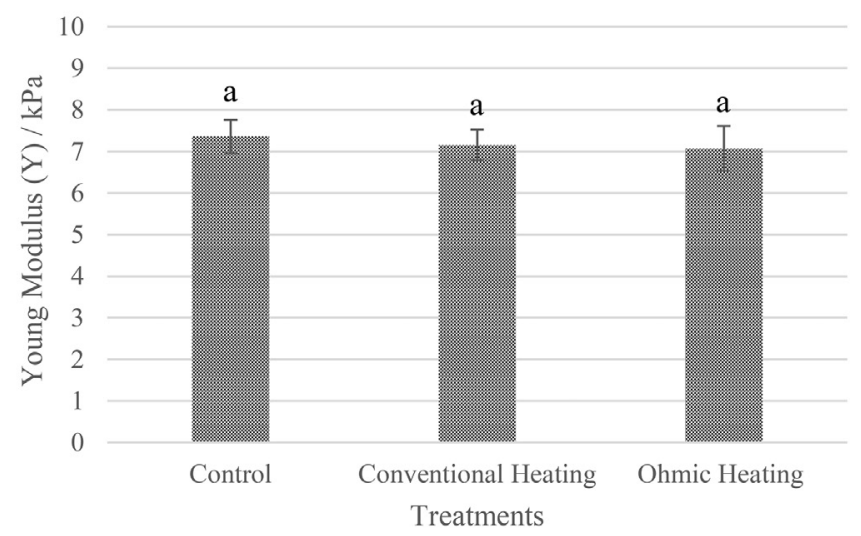

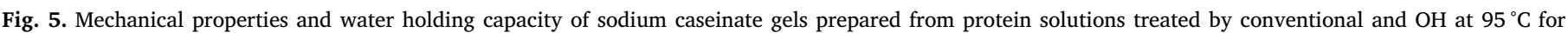


between samples ( $\mathrm{p}<0.05)$.

(employing GDL, for example), due to the development of a three-dimensional protein network (Broyard \& Gaucheron, 2015; Dickinson, 2006; Kuhn et al., 2009).

Gels were prepared after $\mathrm{OH}$ treatment of NaCAS solutions and GDL acidification. $\mathrm{OH}$ was performed at an electric field intensity of approximately $9 \mathrm{~V} \cdot \mathrm{cm}^{-1}$, thus attempting to cover the electrical effects on solubility of NaCAS solutions previously observed through multivariate analysis at electric fields ranging from $5 \mathrm{~V} \cdot \mathrm{cm}^{-1}$ to $17 \mathrm{~V} \cdot \mathrm{cm}^{-1}$. Conventional heating was also used to produce NaCAS gels.

Gels pretreated with conventional and $\mathrm{OH}$ showed significant differences $(p<.05)$ when compared to the gel control, particularly in relation to rupture stress and strain, and water holding capacity (Fig. 5a, 5b and 5d). Rupture stress values (associated to gel hardness) showed the greatest difference between the heating treatments and the control (Fig. 5b), thus agreeing with the multivariate analysis that showed non-homogeneity between unheated and heated samples. It means that heating treatments, even considering sub-lethal temperatures $\left(<100^{\circ} \mathrm{C}\right)$ for this type of protein, could induce conformational changes (i.e. increase of random coil structures) impacting its technological functionality. Nevertheless, regardless of the type of heat treatment applied (with or without the presence of an electric field), and although the gels produced were prone to syneresis (WHC), they always showed to be self-standing (Fig. 6).

In general, the gels formed by conventional or $\mathrm{OH}$ did not differ significantly from each other $(p>.05)$. However, only those treated under the effect of electricity presented less water holding capacity when compared with the unheated samples $(p<.05)$. When we discussed the influence of electric field and its intensity on the NaCAS solutions, we noticed that the protein became more soluble (lower precipitation) at the pI with the increase of the intensity of the electric field applied. Such alteration may have caused a change in the gel network formation, leading to a decrease in the water holding capacity.

Hydrophobic interactions, as well as electrostatic forces (Horne, 1998), are an important requirement to the development of a threedimensional protein network, and thus to gel formation (Dickinson, 2006; McMahon, Du, McManus, \& Larsen, 2009). Considering that the same conditions of temperature and acidification were employed for all systems, it can be hypothesized that changes found between NaCAS gels are the result of alterations in hydrophobic interactions and electrostatic forces between caseins. Changes in NaCAS conformation result in the exposure of unique hydrophobic domains, affecting its solubility and functional properties (Jahaniaval et al., 2000). The synergistic combination between heating and the presence of MEF may have imposed disturbances and re-orientation of hydrophobic residues and redistributions of charges, thus affecting the establishment of a three-dimensional network, and consequently, properties like the WHC of the developed gel.

\section{Conclusions}

This study evaluated effects of $\mathrm{OH}$ and its MEF on the functional properties of NaCAS. Heating pre-treatments, even below ultra-high temperature regimes, induced changes in the NaCAS acidified gels. Multivariate analysis allowed to verify that the application of MEF at different intensities can promote different patterns of physical properties of NaCAS solutions, particularly in respect to protein solubility at the isoelectric point, together with inferences in hydrophobic interactions. Conventional and $\mathrm{OH}$ give rise to gels with similar mechanical 

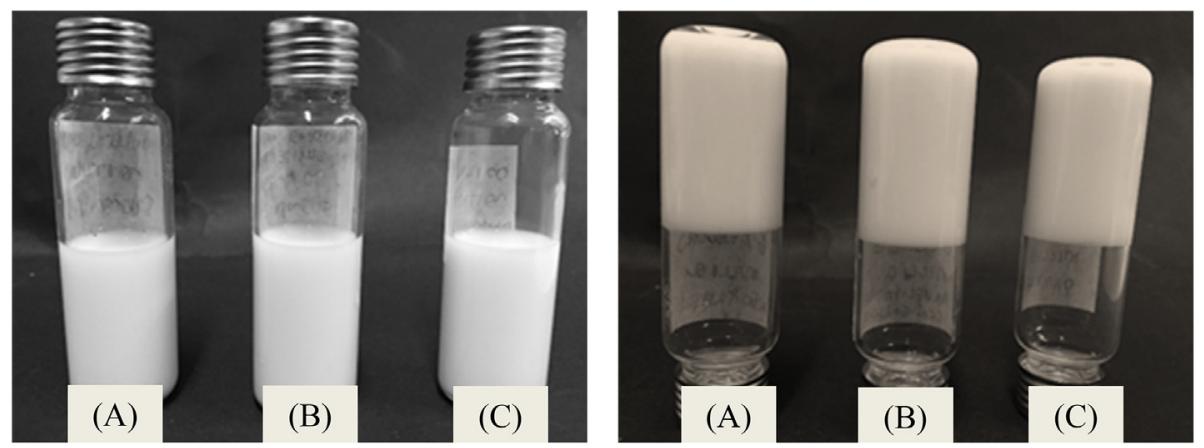

Fig. 6. Sodium caseinate gels prepared from protein solutions treated under conventional and OH and without treatment. (A) Control, (B) Conventional Heating and (C) $\mathrm{OH}$.

features, but the structural alterations promoted by $\mathrm{OH}$ were sufficient to produce a gel with less water holding capacity, while there were no statically significant difference between unheated and conventional heated samples.

These results suggest potential applications of ohmic heated NaCAS in acidic gel systems or fluid foods. Moreover, the effects of electroheating on the increase of NaCAS solubility towards acidification may disclosure new functionalities or facilitate interactions with other proteins that should be explored in future research. Application of electrical fields at sterilization temperatures should also be considered since it could increase the magnitude of protein conformational disturbances and thus bring new technological functional properties to the produced gels.

\section{Acknowledgments}

This work was supported by the Conselho Nacional de Desenvolvimento Científico e Tecnológico - Brazil (401660/2013-3) and supported by the Portuguese Foundation for Science and Technology (FCT) under the scope of the strategic funding of UID/BIO/ 04469 unit and COMPETE 2020 (POCI-01-0145-FEDER-006684) and BioTecNorte operation (NORTE-01-0145-FEDER-000004) funded by the European Regional Development Fund under the scope of Norte2020 - Programa Operacional Regional do Norte. The author Thais Caldas Paiva Moreira thanks Conselho Nacional de Desenvolvimento Científico e Tecnológico (CNPq) for fellowship (207273/2015-4). Ricardo N. Pereira gratefully acknowledge to Portuguese Foundation for Science and Technology (FCT) the financial grant with reference SFRH/BPD/81887/2011. We also acknowledge Alibra Ingredientes Ltda. (Brazil) for protein samples donation.

\section{References}

Aguilera, J. M., \& Rademacher, B. (2004). In R. Y. Yada (Ed.). Protein gels. Boca Raton: CRC Press.

Barreto, P. L. M., Roeder, J., Crespo, J. S., Maciel, G. R., Terenzi, H., Pires, A. T. N., \& Soldi, V. (2003). Effect of concentration, temperature and plasticizer content on rheological properties of sodium caseinate and sodium caseinate/sorbitol solutions and glass transition of their films. Food Chemistry, 82(3), 425-431.

Birlouez-Aragon, I., Sabat, P., \& Gouti, N. (2002). A new method for discriminating milk heat treatment. International Dairy Journal, 12(1), 59-67.

Braga, A. L. M., Menossi, M., \& Cunha, R. L. (2006). The Effect of the Glucono- d-Lactone/ Caseinate Ratio on Sodium Caseinate Gelation. vol. 16, 389-398.

Broyard, C., \& Gaucheron, F. (2015). Modifications of structures and functions of caseins: A scientific and technological challenge. Dairy Science and Technology, 95(6), 831-862.

Chen, H. (2002). Formation and properties of casein films and coatings. In A. Gennadios (Ed.). Protein-based Films and Coatings. Boca Raton: CRC Press.

Chen, J., Dickinson, E., \& Edwards, M. (1999). Rheology of acid-induced sodium caseinate stabilized emulsion gels. Journal of Texture Studies, 30(4), 377-396.

Destefanis, G., Barge, M. T., Brugiapaglia, a., \& Tassone, S. (2000). The use of principal component analysis (PCA) to characterize beef. Meat Science, 56(3), 255-259.

Dickinson, E. (2006). Structure formation in casein-based gels, foams and emulsions. Colloids and Surfaces A: Physicochemical and Engineering Aspects, 288(1-3), 3-11.

Fox, P. F., \& Mcsweeney, P. L. H. (1998). Dairy chemistry and biochemistry. Dairy
Chemistry and Biochemistry. Vol. 1542(9). Dairy Chemistry and Biochemistry (pp. 478) .

Furtado, G.d. F., Mantovani, R. A., Consoli, L., Hubinger, M. D., \& da Cunha, R. L. (2017). Structural and emulsifying properties of sodium caseinate and lactoferrin influenced by ultrasound process. Food Hydrocolloids, 63, 178-188.

Greenfield, N. J. (2007). Using circular dichroism spectra to estimate protein secondary structure. Nature Protocols, 1(6), 2876-2890.

Gunasekaran, S., \& Solar, O. (2012). Heat-Induced Casein - Whey Protein Interactions. Food Proteins and Peptides: Chemistry, Functionality, Interactions, and Commercialization (pp. 199-228). .

Hadjsadok, A., Pitkowski, A., Nicolai, T., Benyahia, L., \& Moulai-Mostefa, N. (2008). Characterisation of sodium caseinate as a function of ionic strength, $\mathrm{pH}$ and temperature using static and dynamic light scattering. Food Hydrocolloids, 22(8), $1460-1466$.

Hidalgo, M. E., Riquelme, B. D., Alvarez, E. M., Wagner, J. R., \& Risso, P. H. (2012). Acidinduced aggregation and gelation of bovine sodium caseinate- carboxymethylcellulose mixtures. In B. Valdez (Ed.). Food Industrial Processes - Methods and Equipament. In Tech.

Horne, D. S. (1998). Casein interactions: Casting light on the black boxes, the structure in dairy products. International Dairy Journal, 8(3), 171-177.

Huppertz, T., \& Patel, H. (2012). Advances in milk protein. In D. Ghosh, S. Das, D. Bagchi, \& R. B. Smarta (Eds.). Innovation in healthy and functional foods. Boca Raton: CRC Press.

Ioannou, J. C., Donald, A. M., \& Tromp, R. H. (2015). Characterising the secondary structure changes occurring in high density systems of BLG dissolved in aqueous $\mathrm{pH} 3$ buffer. Food Hydrocolloids, 46, 216-225.

Jahaniaval, F., Kakuda, Y., Abraham, V., \& Marcone, M. F. (2000). Soluble protein fractions from $\mathrm{pH}$ and heat treated sodium caseinate: Physicochemical and functional properties. Food Research International, 33(8), 637-647.

Kinsella, J. E., \& Morr, C. V. (1984). Milk proteins: Physicochemical and functional properties. Critical Reviews in Food Science and Nutrition, 21(3), 197-262.

de Kruif, C. G. (1997). Skim milk Acidification. Journal of Colloid and Interface Science, 185.

Kuhn, K. R., Picone, C. S. F., \& Cunha, R. L. (2009). Food Gels, (Nishinari). 111-144.

Lucey, J. A., Johnson, M. E., \& Horne, D. S. (2003). Invited Review: Perspectives on the Basis of the Rheology and Texture Properties of Cheese. Journal of Dairy Science, 86(9), 2725-2743.

McMahon, D. J., Du, H., McManus, W. R., \& Larsen, K. M. (2009). Microstructural changes in casein supramolecules during acidification of skim milk. Journal of Dairy Science, 92(12), 5854-5867.

Advanced Dairy Chemistry - 1 Proteins. In P. L. H. McSweeney, \& P. F. Fox (Vol. Eds.), PART A. Proteins(3rd ed). Vol. 1. New York: Springer.

Mezdour, B. S., \& Korolczuk, J. (2010). Particle size distribution of sodium caseinate in water-ethanol solutions. Milchwissenschaft - Milk Science International, 65(2), 3-5.

Normal, I. (2000). Milk proteins. Fundamentals of Cheese Science(0).

O'Kennedy, B. T., Mounsey, J. S., Murphy, F., Duggan, E., \& Kelly, P. M. (2006). Factors affecting the acid gelation of sodium caseinate. International Dairy Journal, 16(10), 1132-1141.

Pereira, R. N., Rodrigues, R. M., \& Teixeira, J. A. (2015). Aquecimento Óhmico: uma ferramenta ao serviço da biotecnologia. Boletim de Biotecnologia, 41-43.

Pereira, R. N., Souza, B. W. S., Cerqueira, M. A., \& Teixeira, A. (2010). Effects of Electric Fields on Protein Unfolding and Aggregation: Influence on Edible Films Formation. 2912-2918.

Pereira, R. N., Teixeira, J. A., \& Vicente, A. A. (2011). Exploring the denaturation of whey proteins upon application of moderate electric fields: A kinetic and thermodynamic study. Journal of Agricultural and Food Chemistry, 59(21), 11589-11597.

Rodrigues, R. M., Martins, A. J., Ramos, O. L., Malcata, F. X., Teixeira, J. A., Vicente, A. A., \& Pereira, R. N. (2015). Influence of moderate electric fields on gelation of whey protein isolate. Food Hydrocolloids, 43, 329-339.

Roefs, S. P. F. M., \& Van Vliet, T. (1990). Structure of acid casein gels 2. Dynamic measurements and type of interaction forces. Colloids and Surfaces, 50(C, 161-175.

Sakurai, K., \& Goto, Y. (2007). Principal component analysis of the pH-dependent conformational transitions of bovine beta-lactoglobulin monitored by heteronuclear NMR. Proceedings of the National Academy of Sciences of the United States of America, 104(39), 15346-15351. 
Snyder, B. S., Haub, M. D., Snyder, B. S., Haub, M. D., Snyder, B. S., \& Haub, M. D. (2007). Whey, casein, and soy proteins. In J. A. Driskell (Ed.). Sports nutrition: fats and proteins (Driskell) (pp. 143-163). Boca Raton: CRC Press.

Steffe, J. F. (1996). Rheological methods in food process engineering. East Lansing: Freeman Press.

Thompson, A., Boland, M., \& Singh, H. (Eds.). (2008). Milk Proteins: From Expression to Food. Boston: Academic Press.
Vicente, A.A., Castro, I. de, \& Teixeira, J.A. (2005). Ohmic heating for food processing. In Thermal Food Processing: New Technologies and Quality Issues (Sun, D.W.). Boca Raton: CRC Press.

Walstra, P., Wouters, J. T. M., Geurts, T. J., \& Walstra, Pieter; Wouters, Jan T.M.; Geurts, T.J. (2005). Milk Components. In Dairy Science and Technology (p. 763). Boca Raton: CRC Press. 